\title{
The New Consensus Macroeconomics: an unreliable guide for policy
}

\author{
Philip Arestis" \\ Malcolm Sawyer"*
}

\begin{abstract}
This paper outlines the New Consensus Macroeconomics, and discusses three important aspects closely related to it: economic policy implications for both monetary and fiscal policies; we deal with the 'natural rate of interest' from a number of perspectives, but most crucially we discuss how this concept is of central importance to the New Consensus Macroeconomics; we also discuss some of the issues and problems surrounding natural rate of interest, including what it is meant to represent, issues of uniqueness and what happens if the rate of interest is not equal to the natural rate. The central role of the Phillips' curve in the New Consensus Macroeconomics and the control of inflation is another aspect we deal with in this contribution. We offer a critique of the new Keynesian Phillips' curve, a critical focus of the New Consensus Macroeconomics.
\end{abstract}

Keywords: New Consensus in Macroeconomics, Monetary Policy, 'Natural Rate' Of Interest, New Phillips Curve.

Resumo: O artigo apresente o Novo Consenso Macroeconômico e discute três importantes aspectos relacionados a ele: as implicações de políticas fiscal e monetária; a importância do conceito de 'taxa natural de juros' para o Novo Consenso Macroeconômico; e as conseqüências quando a taxa de juros difere da 'taxa natural de juros'. Ademais, o papel central da curva de Phillips no Novo Consenso Macroeconômico e o controle da inflação são outros aspectos a serem analisados. Nesse sentido, o artigo apresenta a crítica da curva de curva de Phillips novo keynesiana ao foco central do Novo Consenso Macroeconômico.

Palavras-chave: Novo Consenso Macroeconômico, Política Monetária, 'Taxa Natural de Juros', Nova Curva de Phillips.

JEL Classification: E10; E12.

\section{Introduction}

A New Consensus in Macroeconomics (NCM in short) has emerged over the past decade or so, which has become highly influential in terms of current macroeconomics thinking and of macroeconomic

\footnotetext{
* University of Cambridge

** University of Leeds
} 
policy, especially monetary policy. The NCM is now firmly established amongst both academia and economic policy circles. It is also true to say that it draws heavily on the so-called new Keynesian economics (see MEYER, 2001, for a introduction, WOODFORD, 2003, for very detailed elaboration albeit using the term neo-WICKSELLIAN and the Bank of England, 2005, for a model along NCM lines in the context of building a macro-economic model).

Monetary policy came to the fore from the 1970's onwards as the major component of macroeconomic policy and directed towards the control of inflation driven by the doctrine of monetarism. Monetarism viewed money as exogenous and the cause of inflation, and the control of the money supply became the monetary policy instrument. In contrast, the NCM treats money as endogenous and the policy rate of interest is used as the monetary policy instrument. But the view remains that monetary policy is the policy of choice for the control of inflation. The reason for the emergence of NCM as a different paradigm from the monetarist tradition is the well-known one that the experiments with money supply targeting were a cascading disaster both the US and the UK, and elsewhere, in the late 1970's/early 1980's.

Monetarism, following Friedman (1968), incorporated the Phillips' curve notion whereby there is a short-run trade-off between inflation and unemployment but that in the long-run (which may be reached rather quickly) when expectations of inflation are fulfilled the Phillips' curve is vertical at the 'natural rate of unemployment'. The Phillips' curve continues to play a central role in the NCM providing the mechanism whereby variations in demand impact on inflation and also involving a supply-side equilibrium which, it is asserted, cannot be influenced by the path of demand.

This paper begins by outlining the NCM with the central intention of considering whether it provides a reliable guide on which to base macroeconomic policy. In doing so we focus on two crucial features of the NCM, namely the idea of a 'natural rate of interest' (following WICKSELL, 1898) which is an equilibrium rate in the sense of ensuring equality between savings and investment at full employment and being consistent with a constant rate of inflation, and the Phillips' curve with a short-run relationship between inflation and the level of economic activity but a long-run position equivalent to the supplyside equilibrium.

\section{The NCM formulation}

The NCM can be viewed as based on a form of inter-temporal general equilibrium as in, notably, Woodford (2003). But it can be 
well represented in terms of a few key equations (in part because of the heavy use of the notion of the representative economic agent), and these equations provide a good guide to the NCM particularly when attention is paid to the underlying rationale for each of the equations. We present here, following Meyer, 2001, a three-equation version as follows: ${ }^{1}$

$$
\begin{aligned}
& Y^{g}=a_{0}+a_{1} Y^{g}{ }_{t-1}+a_{2} E_{t}\left(Y_{t+1}^{g}\right)-a_{3}\left[R_{t}-E_{t}\left(p_{t+1}\right)\right]+s_{1} \\
& p_{t}=b_{1} Y_{t}^{g}+b_{2} p_{t-1}+b_{3} E_{t}\left(p_{t+1}\right)+s_{2} \\
& R_{t}=R R^{*}+E_{t}\left(p_{t+1}\right)+c_{1} Y_{t-1}^{g}+c_{2}\left(p_{t-1}-p^{T}\right)+c_{3} R_{t-1}
\end{aligned}
$$

with $b_{2}+b_{3}=1$; where $Y^{g}$ is the output gap, $R$ is nominal rate of interest, $\mathrm{p}$ is rate of inflation, $\mathrm{p}^{\mathrm{T}}$ is inflation rate target, $\mathrm{RR}^{*}$ is the 'equilibrium' real rate of interest (equivalent to the 'natural' rate of interest; see below), that is the rate of interest consistent with zero output gap which implies from equation (2), a constant rate of inflation; $\mathrm{s}_{\mathrm{i}}$ (with $\mathrm{i}=1,2$ ) represents stochastic shocks, and $\mathrm{E}_{\mathrm{t}}$ refers to expectations held at time $\mathrm{t}$.

Equation (1) can be viewed as the equivalent of an IS curve and represents the demand side of the economy with the current output gap determined by past and expected future output gap and the real rate of interest. This equation is derived from optimisation of expected life-time utility subject to a budget constraint (see, for example, BLANCHARD; FISCHER, 1989, Chapter 2). Households and firms have perfect foresight, and know the current and future values of wages and rental rates. A condition, sometimes known as a non-Ponzi game (NPG) condition is imposed which "prevents families from choosing such a path [with higher and higher levels of borrowing], with an exploding debt relative to the size of the family. At the same time we do not want to impose a condition that rules out temporary indebtedness. A natural condition is to require that family debt not increase asymptotically faster than the interest rate" (BLANCHARD; FISCHER, 1989, p. 49). Three features of this approach should be noted. First, the no-Ponzi game condition leads to the implication that lifetime consumption is equal to lifetime income (each suitably discounted). At the individual level, this comes from a combination of a non-satiation assumption along with a no final debt condition. Second, the income of the individual depends on labour supply at the given wage and of capital, and the implicit assumption that the individual is able to

1 We rely heavily on previous contributions in terms of explaining NCM. See, for instance, Arestis and Sawyer $(2005,2008)$ and Sawyer (2008). Arestis (2007) extends the NCM analysis to the open economy case by utilising six equations. 
supply their labour. There is a full employment assumption. The combination of these two features means that at the aggregate level there is the equivalent of Say's Law: potential supply (of labour) leads to actual supply of labour, and the resulting income is fully spent. Third, the consumption decision is made at the level of the household or family under perfect foresight. We can then observe that objections made be raised to the notion of intertemporal optimisation along the lines of 'unrealism' in terms of the information on the future levels of income, interest rates etc. Which are required, and the computational requirements to solve the optimisation problem. There is no consideration given to uncertainty about the future, to learning and the change in household membership. A certain (or certainty equivalent) future is postulated. Significantly there is little room for learning in this process. A further complication arises from whether the optimisation is carried out at the individual level or the household level. If the decision is at the individual level, then some consideration should be given to income sharing within a household. If the decision is presented as being made at the household level then there should be some recognition of changing household composition - children grow up, household split etc.

Equation (2) is a Phillips curve with inflation based on current output gap and past and future inflation. As Gordon (1997, p. 17) remarked (though not in the context of the NCM), "in the long run inflation is always and everywhere an excess nominal GDP phenomenon. Supply shocks will come and go. What remains to sustain longrun inflation is steady growth of nominal GDP in excess of the growth of natural or potential real output". The Phillips' curve underlies the NCM approach to monetary policy in two senses. First, the use of interest rates to target inflation draws on the linkage: interest rate aggregate demand - economic activity - inflation, and the Phillips' curve is the final link in that chain. The sole use of monetary policy in the form of interest rates to target the rate of inflation would be difficult to justify without that final link in the chain. Second, the notion of the trade-off between inflation and unemployment has been used to argue the case for independence of central banks on the grounds that politicians are tempted to stimulate the economy to reduce unemployment without regard for the longer-term inflationary consequences.

Equation (3) is a monetary policy-operating rule (of the Taylor's rule form; see TAYLOR, 1993) with the nominal interest rate based on expected inflation, output gap, and deviation of inflation from target as well as the 'equilibrium' real rate of interest. The lagged interest rate represents interest rate 'smoothing' undertaken by the 
monetary authorities (see, for example, MCCALLUM, 2001). ${ }^{2}$ Equation (3) clearly endogenises the setting of interest rate by the Central Bank and does so along the lines of 'Taylor's rule' (TAYLOR, 1993). The significance of the use of 'Taylor's rule' is twofold. First, it treats the setting of interest rates as a domestic matter without direct reference to international considerations such as the exchange rate and interest rates elsewhere in the world, and those international considerations would only enter Taylor's rule through effects on the domestic variables of output gap and inflation rate. Second, the interest rate is adjusted in response to the output gap (and to the rate of inflation which in turn is modelled to depend on the output gap). A zero output gap is consistent with constant inflation, as can be seen from equation (2). Equation (3) then implies a nominal rate of interest which translates into a real rate equal to the 'equilibrium' rate $R^{*}$, which is consistent with zero output gap and constant inflation. From equation (1), the value of $\mathrm{RR}^{*}$ would need to be $\mathrm{a}_{0} / \mathrm{a}_{3}$. Provided that the Central Bank has an accurate estimate of $\mathrm{RR}^{*}$ then it appears that the economy can be guided to an equilibrium of the form of a zero output gap and constant inflation (at an interest rate equal to the pre set target). In this case, equation (1) indicates that aggregate demand is at a level that is consistent with a zero output gap. In a private sector economy, this would imply that the real interest rate $\mathrm{RR} *$ brings equality between (ex ante) savings and investment. The equilibrium rate of interest corresponds to the Wicksellian 'natural rate' of interest, which equates savings and investment at a supply-side equilibrium level of income.

In effect, the model portrays an economy in which the interest rate can be adjusted to secure equilibrium in terms of a zero output gap and a balance between aggregate demand and aggregate supply (alternatively between planned savings and planned investment). Equation (1) relates the output gap from a demand perspective to expected future output gap, and the rate of interest. First, though, note that the emphasis is on the output gap that is the gap between actual level of output and the "normal' or trend rate of output. It is assumed that the 'normal' or trend rate of output is set on the supplyside of the economy. In effect this trend rate of output is a function

\footnotetext{
2 A fourth equation can be added, which relates the stock of money to 'demand for money variables' such as income, prices and the rate of interest, which would reinforce the endogenous money nature of this approach with the stock of money being demand determined. Clearly, though, such an equation would be superfluous in that the stock of money thereby determined is akin to a residual and does not feed back to affect other variables in the model.
} 
(via a production function) of the factor inputs of labour, capital etc... Second, the real rate of interest is included, and this reflects the role of a comparison between present consumption and future consumption in terms of discounting the future.

There are a number of features of the NCM which should be drawn out as being particularly relevant for the analysis of monetary and fiscal policy. These are:

(I) the perfect capital market assumption: specifically the absence of credit rationing (which would mean that some individuals were credit constrained) and the assumption of a single interest rate. This would mean that the only effect of monetary policy would be a 'price effect' as the rate of interest is changed. The parts of the transmission mechanism of monetary policy, which involve credit rationing and changes in the non-price terms on which credit is supplied would be excluded by assumption.

(II) there is no mention of banks in this analysis. It has been noted that in the major text of Woodford (2003) banks make no appearance in the index (GOODHART, 2004). Since banks and their decisions play a considerably significant role in the transmission mechanism of monetary policy, and further that decisions by banks as to whether or not to grant credit plays a major role in the expansion of the economy (in the sense that a failure of banks to supply credit would imply that expansion of expenditure cannot occur), there is a disjuncture between this analysis and the role of monetary policy.

(III) the role for investment. The basic analysis (WOODFORD, 2003, Chapter 4) is undertaken for households optimising their utility function in terms of the time path of consumption. ${ }^{3}$ Investment can then be introduced in terms of the expansion of the capital stock, which is required to underpin the growth of income. In effect the future path of the economy is mapped out, and consequently the time path of the capital stock. Investment ensures the adjustment of the capital stock to that predetermined time path. There is then by assumption no impact of the path of the economy on the capital stock. There is not what we may term an independent investment function in the sense of arising from firms' decisions taken in the light of profit and growth opportunities, separated from savings decisions of households.

3 "One of the more obvious omissions in the basic neo-Wicksellian model developed in Chapter 4 is the absence of any effect of variations in private spending upon the economy's productive capacity and hence upon supply costs in subsequent periods" (WOODFORD, 2003, p. 352). 


\section{The 'natural rate of interest' and macroeconomic policy}

The 'natural rate of interest' plays a crucial role in the NCM. In terms of the three equations above, it is clear that a rate of interest in real terms equal to the 'natural rate of interest' secures output at the supply equilibrium level (zero output gap) consistent with constant inflation. Another way of putting this result is to say that when the real rate of interest is equal to the 'natural rate', then there is no problem of deficient (or indeed excessive) aggregate demand.

This bold assertion hides many things, which we think are particularly pertinent for macroeconomic policy considerations.

First, it is noteworthy that the model is set up in terms of 'the' rate of interest, which is identified with the policy rate of interest (which is adjusted according to equation (3)). The implicit assumptions here are that the interest rates (e.g. on loans), which are relevant for decision makers (over investment and savings) move in line with the policy rate of interest, and that it is the policy rate which is exogenous as far as the private sector is concerned, albeit that it is varied by the Central Bank in accordance with deviations of inflation from target and the output gap. It is also implicitly assumed that decisions on investment (and indeed consumption) are made in response to the cost of finance (that is the rate of interest) with no allowance for credit rationing and the like.

Second, the policy interest rate is the adjustment tool by which the economy moves towards equilibrium (zero output gap and constant rate of inflation). But the adjustment is undertaken by the Central Bank, and depends on the Central Bank following an appropriate decision rule. Equation (3) appears as such a decision rule but even so depends on knowledge of the 'natural rate' of interest, an issue to which we return below.

Third, fiscal policy is ruled out by omission. The three-equation model outlined above appears to offer little opportunity for fiscal policy. It would be possible to interpret the coefficient $\mathrm{a}_{0}$ in equation (1) as a shift variable reflecting the fiscal stance. It would, of course, be the case that the equilibrium level of output is unaffected by fiscal policy. If the fiscal stance were changed, this would be reflected in a change in $\mathrm{a}_{0}$, the implication from this model is that the 'natural rate' of interest (which can be solved out as $\mathrm{a}_{\mathrm{d}} / \mathrm{a}_{3}$ ) would also change so as to leave the equilibrium level of aggregate demand unchanged and compatible with the equilibrium level of output. Fiscal policy could be compared in terms of its stabilising properties with monetary policy by the use of a 'fiscal policy Taylor's rule' whereby the fiscal stance 
changes in response to deviations of inflation from its target and output from its equilibrium level. Equation (3) is asserted to reflect actual practice, even though fiscal policy may be adjudged more powerful.

However, there is a strong sense in which fiscal policy is deemed impotent in this approach by construction. As indicated above, there is the idea of an intertemporal budget constraint at the level of the individual, and then by construction at the level of the private sector. Under this budget constraint, there is an essential equality between income and expenditure and savings and investment. There is then a corresponding government budget constraint. This takes the form of "the government's intertemporal budget constraint... It states that the current level of debt must be equal to the present discounted value of primary surpluses. If the government is currently a net debtor, it must intend to run primary surpluses at some time in the future" (BLANCHARD; FISCHER, 1989, p. 127, emphasis in original).

This approach nullifies any requirement (or effect) of fiscal policy for two interrelated reasons. First, it is an accounting requirement that the private sector surplus plus the public sector surplus sum to zero (in the context of a closed economy). Hence, if the private sector is, over time, constrained to have a balanced budget along the full employment path, then so must the public sector. But since the private sector is spending all its income, full employment is assured and there is no space for a public sector budget deficit. Second, there is Ricardian equivalence so far as the households are concerned. Hence any fiscal stimulus by government would be completely offset by the response of the private sector.

Fourth, by extension from the previous point, any variations in the fiscal stance (and indeed variations in factors influencing investment, and in an open economy context, variations in foreign demand) would lead to a variation in the 'natural rate of interest'. The real interest rate is at an equilibrium level of $R^{*}$, which can be seen to be equal to $a_{0} / a_{3}$. This equilibrium rate is often seen to correspond to what is called the Wicksellian 'natural rate' of interest. Wicksell (1898) distinguished between the money rate of interest (as observed) and the 'natural rate' of interest, which was the interest rate that was neutral to prices in the real market, and the interest rate at which supply and demand in the real market was at equilibrium. The idea that $a_{0}$ in equation ( 1 ) would change with fiscal policy severely undermines the concept of the 'natural rate of interest' in two respects. First, it becomes evident that the 'natural rate of interest' would depend on a key component of aggregate demand, namely fiscal policy. Second, it destroys any notion of a unique 'natural rate'. 
Although it is not self-evident from the model outlined above, this 'natural rate' of interest equates savings and investment and does so at a zero output gap. This is implicitly assumed to be consistent with the full employment of labour in that flexible real wages would permit the labour market to clear with full employment compatible with the zero output gap. Although the rate of interest is set by the Central Bank, the loanable funds view of interest rate determination is reinstated. This takes us back to a pre-Keynesian position (in the The General Theory of Employment, Interest and Money sense; GT in short) as described by Keynes himself. In his Treatise on Money, Keynes (1930, p. 139), states that "Following Wicksell, it will be convenient to call the rate of interest which would cause the second term of our fundamental equation to be zero the natural rate of interest, and the rate which actually prevails the market rate of interest. Thus the natural rate of interest is the rate at which saving and the value of investment are exactly balanced, so that the price level of output as a whole (P) exactly corresponds to the money rate of the efficiency earnings of the factors of production. Every departure of the market rate from the natural rate tends, on the other hand, to set up a disturbance of the price level by causing the second term of the second fundamental equation to depart from zero. We have, therefore, something with which the ordinary quantity equation does not furnish us, namely, a simple and direct explanation why a rise in the bank rate tends, in so far as it modifies the effective rates of interest, to depress price levels".

However, in GT, Keynes (1936) explicitly rejects the idea of a unique natural rate of interest, and in effect argues that there is a natural rate of interest corresponding to each level of effective demand, which would bring savings and investment into balance. "In my Treatise on Money I defined what purported to be a unique rate of interest, which I called the natural rate of interest - namely, the rate of interest which, in the terminology of my Treatise, preserved equality between the rate of saving (as there defined) and the rate of investment... I had, however, overlooked the fact that in any given society there is, on this definition, a different natural rate of interest for each hypothetical level of employment. And, similarly, for every rate of interest there is a level of employment for which the rate is the 'natural' rate, in the sense that the system will be in equilibrium with that rate of interest and that level of employment. Thus it was a mistake to speak of the natural rate of interest or to suggest that the above definition would yield a unique value for the rate of interest irrespective of the level of employment. I had not then understood 
that, in certain conditions, the system could be in equilibrium with less than full employment" (KEYNES, 1936, p. 242-243).

It is also the case that a shift in the state of confidence and expectations leading to a shift in the investment schedule would lead to a shift in the natural rate of interest. Keynes (1936, p. 243-244) went on to argue that "If there is any such rate of interest, which is unique and significant, it must be the rate which we might term the neutral rate of interest, namely, the natural rate in the above sense which is consistent with full employment, given the other parameters of the system; though this rate might be better described, perhaps, as the optimum rate... The above gives us, once again, the answer to the question as to what tacit assumption is required to make sense of the classical theory of the rate of interest. This theory assumes either that the actual rate of interest is always equal to the neutral rate of interest in the sense in which we have just defined the latter, or alternatively that the actual rate of interest is always equal to the rate of interest which will maintain employment at some specified constant level. If the traditional theory is thus interpreted, there is little or nothing in its practical conclusions to which we need take exception. The classical theory assumes that the banking authority or natural forces cause the market-rate of interest to satisfy one or other of the above conditions".

The NCM model portrays an economy in which the interest rate can be adjusted to secure equilibrium in terms of a zero output gap and a balance between aggregate demand and aggregate supply (alternatively between planned savings and planned investment). There are (at least) six factors that may prevent this from coming about, and which would upset the conclusion that interest rate policy can guide the economy to equilibrium with demand and supply in balance and inflation on target.

The first is that the 'equilibrium' rate of interest is either negative or positive but so low as to be unattainable. ${ }^{4}$ In terms of the equations given above this would correspond to the real rate of interest given by $a_{0} / a_{3}$ being low or negative. This would be equivalent to saying that the savings and investment schedules do not intersect in the positive range of interest rates. The aggregate demand equation (1) above clearly assumes that aggregate demand, and presumably investment, is interest rate sensitive (such that $\mathrm{a}_{3}$ is greater than zero)

4 This discussion is in terms of the Central Bank rate. It is assumed that the rate of interest on loans is above the Central Bank rate, and that it is the rate of interest on loans, which is relevant for investment decisions. Given the risks for banks involved in extending loans, it can be assumed that there is a minimum level below which banks would not go in terms of the loan rate. 
and that there is a substantial autonomous component of demand (otherwise $\mathrm{a}_{0}$ would be non-positive).

Second, and not unrelated to the previous point, interest rates may have very little effect on the levels of investment and savings and hence variations in the rate of interest would be ineffectual in reconciling intended savings and investment. The theoretical and empirical arguments on the ambiguity of the sign of the relationship between savings and the rate of interest are well known. The empirical literature on investment has often cast doubt on the impact of interest rates on investment and stressed the roles of profitability and capacity utilisation.

Third, the linkage from the key discount rate set by the Central Bank and the interest rates, which influence economic decisions, may be rather loose and uncertain. For example, the long-term rate of interest may be viewed as relevant for long-term investment decisions, and the response of the long-term rate of interest to changes in the key discount rate may be relatively slight and may vary over time. The banks could respond to a change in the discount rate by a combination of changes in the interest rate on loans and changes in the credit standards, which they set. Hence, the impact of a change in the discount rate on interest-sensitive spending decisions depends on the decisions of banks and other financial institutions.

Fourth, the 'equilibrium' rate of interest has been determined in light of domestic considerations only, and may not be compatible with interest rates in the rest of the world or have severe implications for the capital account balance. ${ }^{5}$

Fifth, the Central Bank cannot calculate and attain the 'equilibrium rate' of interest through reasons of lack of information, it being a moving target. It can be seen in the equations given above that the 'equilibrium rate' depends on $\mathrm{a}_{0} / \mathrm{a}_{3}$ and these are parameters, which can and do vary over time. Mistakes may occur in the setting of interest rates as the Central Bank has imperfect information on the equilibrium real rate of interest $R^{*}$ (assuming that such a rate does actually exist), and may aim for a real rate of interest which is not equal to ad $\mathrm{a}_{3}$. Any shift in fiscal policy, in investors' confidence or in world trade conditions would be reflected in a change in $\mathrm{a}_{0}$, leading thereby to $\mathrm{a}$ change in the equilibrium real rate of interest. This would, of course,

5 As Keynes (1930, p. 192) argued, "the dilemma of modern banking is satisfactorily to combine the two functions. As a purveyor of representative money, it is the duty of the banking system to preserve the prescribed objective standard of money. As a purveyor of loans on terms and conditions of a particular type, it is the duty of the system to adjust, to the best of its ability, its supply of this type of lending to the demand for it at the equilibrium rate of interest, i.e. at the natural rate". 
exacerbate the problems of securing information on the equilibrium rate and exacerbate the chances of policy mistakes. Information on the 'equilibrium rate' is not exactly readily available, and indeed at best can only be estimated with some lag and over a period when it can be reasonably assumed the underlying parameters are stable. A significant issue arises here, namely whether the Central Bank can make systematic mistakes on its estimates of the 'natural rate', and in particular does the Central Bank tend to overestimate the 'natural rate'. The interest rate set by the Central Bank will have an effect on investment decisions, and a generally too high interest rate will lead to lower investment and capital stock. In turn, the capital stock will help determine the 'trend' level of output, and a lower capital stock could lead to a lower 'trend' level of output. Sixth, the Central Bank (or the government) may not wish to attain the 'equilibrium rate' of interest as defined above. In other words, the Central Bank does not pursue a policy rule akin to Taylor's rule.

Sixth, equation (1) and the reasoning, which lies behind it, has two significant implications. First, it expresses output (relative to trend, hence output gap) is equal to demand. In equilibrium the supply is equal to demand, and equivalently (desired) savings equal to (desired) investment. The 'natural rate' of interest brings savings and investment into balance and in that sense could be seen as equivalent to the loanable funds rate of interest. Second, out of equilibrium (that is when the rate of interest is not equal to the 'natural rate') then there is a difference between desired investment and desired savings. But the actual level of investment and savings is equal to desired investment. When the actual rate of interest is above (below) the 'natural rate', it is expected that desired investment is less (more) than desired savings. So even when desired savings is less than desired investment, the desired level of investment occurs, and in effect there is forced savings. Contrary to the argument that out of equilibrium the short side of the market dominates (CLOWER, 1965) in this case investment is treated as dominating. In one sense this can be readily explained: investment expenditure is financed through bank loans, and provided banks are willing to supply the necessary loans at the prevailing rate of interest, the investment expenditure can take place. But it does run counter to loanable funds notions, and also counter to the argument frequently advanced in the financial repression literature that interest rate below equilibrium would lead to low savings and thereby low investment. 


\section{The new Keynesian Phillips curve approach}

The New Keynesian Phillips Curve (NKPC), a central feature of the NCM, can be seen to have its origins in the staggered price setting model of Calvo (1983). The key elements of this approach are as follows. ${ }^{6}$ Each firm produces a differentiated product, faces a constant price elasticity of demand curve for its product. In each period some firms change price but others do not, and in each period a proportion $a$ of firms do not change price, and the probability of a firm changing its price in the period in question is independent of whether it had changed price in the preceding period. The aggregate price level can then be constructed as a weighted average of lagged price level and the optimal price set by those changing price. With the price level (log form) denoted $p$ and optimal price (again $\log$ form) $p^{*}$, the equation is:

$$
p_{t}=\alpha p_{t-1}+(1-\alpha) p_{t}^{*}
$$

The optimal price $p^{*}$ is derived from profit maximising calculations in a forward-looking context. The firm takes into account that its marginal costs will change in the future and that it may or may not change price in any specific period. These considerations lead to the following:

$$
\sum_{T=t}^{\infty}(\alpha \beta)^{T-t} E_{t}\left[p_{t}^{*}-p_{T}-\lambda\left(Y_{T}-Y_{T}^{n}\right)\right]=0
$$

where $\hat{a}$ is the subjective discount factor, $Y_{T}$ and $Y_{T}^{n}$ are output and 'normal' output respectively and ë arises from the sensitivity of marginal cost to output and the mark-up of price over marginal costs. The output term comes in through marginal cost for as Woodford (2003, p. 181) notes "the appearance of the expected log real marginal cost (i.e. the expected gap between log marginal cost and the log price index) in the first order condition... also makes sense insofar as it is this gap, rather than the level of real activity as such, that is directly related to the incentives that suppliers have to adjust their prices". It should specifically be noted that the relationship between marginal cost and output is assumed to be a monotonic and positive one (the output that is relevant as a measure of inflationary pressures should

6 This derivation is based on Woodford (2003, Section 2.1 p. 177-196 and p. 661-2). See, for example, Gali and Gertler (1999) for a similar derivation albeit implicitly based on perfect competition with price equal to marginal cost. 
be monotonically related to variations in the level of real marginal costs). Often a Cobb-Douglas production function is assumed which ensures a positive relationship between marginal cost and output. ${ }^{7}$

Manipulation of equations (4) and (5) then yields:

$$
\pi_{t}=\kappa\left(Y_{t}-Y_{t}^{n}\right)+\beta E_{t}\left\{\pi_{t+1}\right\}
$$

where $\kappa=\frac{(1-\alpha)(1-\alpha \beta)}{\alpha} \lambda$

Equation (6) can, then, be iterated forward to yield:

$$
\pi_{t}=\kappa \sum_{k=0}^{\infty} \beta^{k} E_{t}\left[Y_{t+k}-Y_{t+k}^{n}\right]
$$

There are some rather surprising implications, which come from the NKPC. It has been noted (GALI; GERTLER, 1999, for example) equation (7) implies that the current change in inflation should depend negatively on the lagged output gap (with $\beta \approx 1$, and the difference between expected inflation and actual inflation a random error term). Further, although $\beta$, being the discount factor is likely to be close to unity, the NKPC strictly does not involve a vertical long-run Phillips' curve. A recent contribution has criticised the vertical view of the Phillips curve. Karanasou et al. (2006, p. 36) show that the proposition of a vertical Phillips curve can only be right under the implausible assumption of "symmetric backward and forward-looking elements in the pricesetting behaviour due to no time discounting". When 'intertemporal asymmetry' is introduced a long-run inflation-unemployment tradeoff exists after all. A holistic approach is, then, needed that accounts for the intimate dynamic relation between inflation and unemployment (see, also, BATINI et al., 2005).

A further significant feature emerges from equation (7), namely that the rate of inflation is the sum of expected future real variables, and these variables can be anticipated to have a zero mean as they refer to deviations of output from 'normal' level. This appears to suggest that inflation itself will always be close to zero. An alternative interpretation is that variables have been expressed relative to a steady state inflation rate, and hence $\delta$ would then be interpreted as deviation of inflation from steady state rate, leaving the steady state rate of inflation unexplained.

7 In the case of a Cobb-Douglas production function this equilibrium level of output clearly would not correspond to any physical capacity output nor to a level of output at which average costs are minimised. It could be taken as the level of output which firms would choose to produce given relative prices. 
It can be readily seen from the above derivation that the assumption of rising marginal costs is crucial to the derivation of equation (5). The assumption of a Cobb-Douglas production function, which has often been used in this context, may be questioned on grounds of its empirical relevance (ROWTHORN, 1999). ${ }^{8}$ It is, of course, the case that any positive monotonic relationship between marginal cost and output would be sufficient in this context. However, the notion that firms always operate where marginal costs are rising with output is of dubious empirical relevance. For example, "also relevant to the interpretation of all the empirical work on price determination is the fact that actual unit costs changes fall during booms and rise in recessions" (LAIDLER; PARKIN, 1975, p. 768). Downward (1999) reports some 19 per cent of UK firms agreeing that costs increase with output but 65 per cent agreeing that costs decrease with output. Taylor (1998, p. 23) concludes that "... it would be inaccurate and misleading to build a model in which the average frequency of price [or wage] adjustment is longer than one year".

The dismissal of the traditional U-shaped costs curves with a range of declining unit costs and then range of increasing unit costs in the context of an imperfect competition approach is surprising. The notion of a pricing decision made by a firm (rather than dictated by the market) is closely linked with imperfect competition, and indeed the NKPC is based on firms producing differentiated products. It is also possible that under conditions of imperfect competition firms may well be operating along the declining portion of their cost curves. It then follows that for those firms where marginal costs and output were negatively related, a NKPC would be derived in which price inflation was negatively related to the level of output.

The influence, which the assumption on frequency of price change has on the NKPC approach, can be seen from equation (6). In the case where firms consider changing price every period, i.e. $\beta=0$, then it can be readily seen that equation (6) collapses as the coefficient ê on the deviation of output from normal goes to infinity. In the case where no firms consider changing price, inflation would not depend on the output gap (since the first term in that equation would have zero coefficient) and inflation is solely driven by expected inflation

8 The CES production function has also been used. Harrison et al. (2005) elaborate on the use of the CES production function as follows: "The motivation for using a CES production function, instead of the simpler Cobb-Douglas form, is that the elasticity of investment to interest rates would be unrealistically high under the assumption of Cobb-Douglas technology. Correspondingly, we assume that capital and labour tend to be less substitutable for each other than in the Cobb-Douglas case" (HARRISON et al., p. 34). 
with a coefficient of below unity, hence actual inflation would then always be below expected inflation.

The length of the 'period' for which this analysis is intended then becomes significant. If the period is a calendar year, then causal observation may suggest that all firms consider their prices at least once a year, even if the decision is to leave their prices unchanged. Hall, Walsh, and Yates (1997), in a survey of 654 UK companies, found some 27 per cent of firms reviewed their prices annually, and all of the others more frequently. Following the argument made in the previous paragraph this would imply that the NKPC applied on an annual basis would collapse as the coefficient on output (relative to 'normal' level) would be infinite. If in addition to the formal price review we add in considerations of price adjustments, special promotions etc., then the frequency of price changes would clearly be increased, and may be such as to cast doubt on the usefulness of the above approach for equations based on quarterly observations. It can also be readily calculated from equation (6) that if typically most firms (say 80 or 90 per cent) can their prices (or consider changing their prices) in a given length of time (say a quarter of a year) then the NPKC applied to that length of time period (in this example on a quarterly basis) then the coefficient on deviation of output from normal would become in some sense large: for $\alpha=0.2$, coefficient is $32 \lambda$ (treating $\beta \approx 1$ ), for $\alpha=0.1$ coefficient is $81 \lambda$.

An alternative derivation is provided in Harrison et al. (2005), where the forward-looking profits function includes costs of price adjustment, which are quadratic in firm's own price change relative to the 'steady state' rate of inflation. Around the 'steady state' rate of inflation $\left(p^{\text {ss }}\right)$ with linearization, and symmetry amongst firms, the rate of inflation is given by:

$$
\dot{p}_{t}-\dot{p}^{s s}=\beta\left(\dot{p}_{t+1}-\dot{p}^{s s}\right)+\frac{\eta-1}{\chi}\left(\log R M C-\log \frac{\eta-1}{\eta}\right)
$$

where $\eta$ is the elasticity of demand, RMC real marginal cost and $\chi$ the parameter on the costs of price adjustment term in the profits function. The term $(\eta-1 / \eta)$ is simply the steady-state real marginal cost, based on the equality of marginal cost and marginal revenue. It can be again noted that RMC may be positively or negatively related with output, and that inflation would be seen depend on factors such as movement in the real wage which would impact on RMC. The role of output here (which to repeat may be positive or negative) comes from the relationship between actual mark-up of price over (marginal) cost and the desired (profit maximising) mark-up of price over (marginal) cost which are expressed in terms of real marginal cost 
(RMC) and the desired mark-up (the inverse of $(\eta-1) / \eta)$. However, the approximations, which are used, serve to eliminate the effects of changes in output. A simple representation of this line of argument comes from the following. Consider that the desired (optimal) price for a firm is given by:

$$
p^{*}=\varepsilon+w+c(q)
$$

where variables are measured in logs, and $\AA$ is (log of) mark-up, w wages and $\mathrm{c}(\mathrm{q})$, real marginal costs, which is made a function of output. One approach to this would be to treat actual price changes as a combination of changes in the optimal price and a catch-up term depending on the difference between actual price and desired price. Then price change would be given by:

$$
\dot{p}=\dot{\varepsilon}+\dot{w}+c^{\prime}(q) \cdot \dot{q}+v(\varepsilon+w+c(q)-p)
$$

which clearly involves changes in output. An alternative approach, in effect pursued by the NKPC with staggered price changes, is the following equation:

$$
p-p(-1)=(1-\alpha)\left(p^{*}-p(-1)\right)=(1-\alpha)[\varepsilon+w+c(q)-p(-1)]
$$

where inflation is seen to depend on output in a non-linear fashion, and that inflation arises from attempts to move price to some desired level.

Output enters equation (11) as a proxy for real marginal costs. Real marginal costs are often empirically proxied by the share of labour in national income. When labour is treated as the sole variable factor of production, then (nominal) marginal cost is equal to wage divided by marginal product of labour, and under a Cobb Douglas production function marginal product of labour is equal to the exponent of labour in the production function times the average product of labour. Real marginal cost, that is nominal marginal cost, is then proportional to labour's share in national income. Inflation, which is viewed as responsive to real marginal cost, could also be viewed as inflation responsive to labour's share. Further since share of profits plus share of wages is equal to unity, this is also inflation responsive to share of profits. This interpretation would feed into a conflict theory of inflation since here prices are viewed to rise when share of profits is below some normal or target level.

The NKPC has been criticised for its empirical failures. For example, (MANKIW, 2001, p. C52) argues that "[a]lthough the new Keynesian 
Phillips' curve has many virtues, it also has one striking vice: It is completely at odds with the facts". Chadha and Nolan (2004, p. 271) concur by suggesting that "[a]ttractive though the need to establish a direct inflation-output link may be, as an empirical framework for explaining inflation over the business cycle, the New Keynesian Phillips' Curve (NKPC), in inflation-output space has not been particularly successful". Galì and Gertler (1999, p. 196) have also noted that "it is often difficult to detect a statistically significant effect of real activity on inflation using the structural formulation implied by the theory, when the measure of real activity is an output gap (i.e., real output relative to some measure of potential output). Failure to find a significant short-run link between real activity and inflation is unsettling for the basic story". For the UK, Batini et al. (2005, p. 1066), in a paper on new Keynesian Phillips' curve report, "four core findings. First, inflation appears to be highly forward-looking, with a coefficient on expected inflation equal to $0.69(\mathrm{t}$-value $=8.3)$. Second, as we expected, the labour share term is strongly significant in this equation entering with a coefficient of $0.16(t-v a l u e=4.9)$, which implies that a 1 per cent rise in the share of labour gives rise to a 0.16 percentage point increase in inflation. Third, additional cost elements, namely real import prices and the change in oil prices, are also important. Fourth, the employment terms... are correctly signed and significant in this equation, suggesting that employment adjustment costs are relevant for pricing decisions and hence for inflation in the U.K. On the other hand, in this baseline regression, both variables that capture variations in the equilibrium mark-up, i.e. the state of the business cycle term and the term capturing the impact of foreign competition, are not significant".

The evidence of authors such as Galí and Gertler (1999) and Galí et al. (2005) suggests that real marginal cost (as measured by labour share) is the appropriate variable to include rather than output, which could be seen to also cast doubt on the output-marginal cost link. Galí et al. (2005, p. 1109) argue that "a significant corollary result is that the use of real marginal cost as the relevant real sector forcing variable in the hybrid NKPC (as the theory suggests) is critical to the empirical success. Specifications based instead on ad-hoc 'output gap' measures (e.g., detrended log GDP) do not perform well: the coefficient on the output variable is either insignificant or significant but with the wrong sign. There has been of course considerable criticism of the output-gap based NKPC (e.g., Mankiw, 2001). Our results suggest that a key reason for the lack of success of this formulation is that detrended output is not a good proxy for real marginal cost, in addition to the need to allow for a modest amount of inertial behavior 
of inflation". An alternative interpretation of equation (2) then becomes that inflation arises when labour share deviates from 'trend' value. Specifically when labour's share is relatively high, the rate of price inflation is relatively high, and firms could be seen as seeking to restore their profit margins by raising prices (faster than otherwise).

Batini et al. (2005) discuss the new Keynesian Phillips curve. But their key equation ( 3 in their paper and 12 in this paper) is of the following form:

$$
\pi_{t}=\phi E_{t-1} \pi_{t+1}+\alpha_{1} E_{t-1}(\ln \mu *-\ln \mu)-\alpha_{2} E_{t-1}\left(\phi \Delta n_{t+1}-\Delta n_{t}\right)+v_{t}
$$

where $\pi$ is rate of inflation, ì is actual mark-up and $\grave{i}^{*}$ is target markup, and $n$ employment. This equation has three features: (I) coefficient on expected inflation is not unity; (II) inflation is dependent on difference between target and actual mark-up: mark-up is price/marginal cost, which is in effect the inverse of labour share (under CobbDouglas production function assumption, which is later relaxed; (III) changes in employment are relevant: indeed in this formulation it is close to second difference of employment.

The NKPC then has the feature that the coefficient on expected inflation is less than unity, albeit that the coefficient is relatively close to unity (equation 6 above). If that is accepted then $\pi_{t}(1-\beta)=k\left(Y_{t}-\right.$ $\left.\mathrm{Y}_{\mathrm{t}}^{\mathrm{n}}\right)$ with the implications that there is a long-run trade-off between inflation and the output gap and the inflation target would imply a non-zero output gap: indeed any constant rate of inflation would imply (in general) a non-zero output gap.

The NCM (as indicated by equations (1) to (3) above) relies on the Phillips' curve as a central idea, where the Phillips' curve has the two properties of a (positive) relationship between the rate of inflation and the level of economic activity, and a coefficient of unity on expected inflation (coefficients on past and expected inflation sum to zero). The argument advanced here is that the NKPC does not support the second proposition, and we have argued does not provide support to the first proposition either.

\section{Final Considerations}

The NCM has become associated with the use of monetary policy to target inflation and with the downgrading of fiscal policy. In this paper we have argued that the virtual dismissal of fiscal policy is not well founded and based on a set of arbitrary assumptions. Further, if allowance is made for some potency for fiscal policy then the central 
concept of the NCM in terms of the 'natural rate of interest' is severely undermined.

The use of interest rates to target inflation is based on two propositions. First, that there is a knowable and achievable equilibrium real rate of interest ("natural' rate of interest) which is consistent with constant inflation and supply-side equilibrium (zero output gap). Second, that variations in the nominal policy interest rate influences aggregate demand which in turn sets the rate of inflation. In this paper we have argued that the 'natural rate' of interest is a deficient concept and there is no good reason to think that there is a well-defined unique and achievable equilibrium rate of interest. We have further argued that the Phillips' curve on which the second proposition relies is flawed on theoretical and empirical grounds, and specifically that there is not a well-supported relationship between inflation and the level of economic activity. We may, therefore, overall conclude that the NCM is indeed an unreliable guide for policy.

\section{References}

ARESTIS, P. What is the new consensus in macroeconomics? In: ARESTIS, P. (ed), Is there a new consensus in macroeconomics? Basingstoke: Palgrave-Macmillan, 2007.

ARESTIS, P.; SAWYER, M. New Consensus Monetary Policy: an appraisal. In: ARESTIS, P.; BADDELEY, M.; MCCOMBIE, J. (eds.). The New Monetary Policy: Implications and Relevance. Cheltenham: Edward Elgar, p. 7-22, 2005.

. A critical reconsideration of the foundations of monetary policy in the new consensus macroeconomics framework. Cambridge Journal of Economics, 32 (5), 761779, 2008.

BANK OF ENGLAND. The Bank of England Quarterly Model. London: Bank of England, 2005.

BATINI, N.; JACKSON, B.; NICKELL, S. An open-economy new Keynesian Phillips, urve for the U.K. Journal of Monetary Economics, v. 52, n. 4, p. 1061-1071, 2005.

BLANCHARD, O. J.; FISCHER, S. Lectures on Macroeconomics. Cambridge, USA and London: The MIT Press, 1989.

CALVO, G. A. Staggered prices in a utility maximising framework. Journal of Monetary Economics, v. 12, n. 3, p. 383-398, 1983.

CHADHA, J.; NOLAN, C. Output, inflation and the New Keynesian Phillip's curve. International Review of Applied Economics, v. 18, n. 3, p. 271-288, 2004.

CLOWER, R.W. The Keynesian counter-revolution: a theoretical appraisal. In: HAHN, F.; BRECHLING F. (eds.), The Theory of Interest Rates, London: Macmillan, 1965.

DOWNWARD, P. Pricing Theory in Post Keynesian Economics: A Realist Approach. Aldershot: Edward Elgar, 1999.

FRIEDMAN, M. The Role of Monetary Policy. American Economic Review, v. 58, n. 1, p. 1-17, 1968. 
GALÍ, J.; GERTLER M. Inflation dynamics: a structural econometric analysis. Journal of Monetary Economics, v. 44, n. 2, p. 195-222, 1999.

GALÍ, J.; GERTLER, M.; LÜPEZ-SALIDO, J. D. Robustness of the estimates of the hybrid New Keynesian Phillips curve. Journal of Monetary Economics, v. 52, p. 11071118, 2005.

GOODHART, C.A.E. Review of Interest and Prices by M. Woodford. Journal of Economics, v. 82, n. 2, p. 195-200, 2004.

GORDON, R.J. The time-varying NAIRU and its implications for economic policy, Journal of Economic Perspectives, v. 11, n. 1, p. 11-32, 1997.

HALL, S.; WALSH, M.; YATES, A. How do UK companies set prices? Bank of England Working Paper No. 67, London: Bank of England ,1997.

HARRISON, R.; NIKOLOV, K.; QUINN M.; RAMSAY, G.; SCOTT, R.; THOMAS R. The Bank of England Quarterly Model, London: Bank of England, 2005.

KARANASSOU, M.; SALA, H.; SNOWER, D. J. Phillips curves and unemployment dynamics: a critique and a holistic perspective. Discussion Paper No. 2265, Bonn, Germany: IZA, 2006.

KEYNES, J.M. A Treatise on Money: The Pure Theory of Money. London: Macmillan. 1930. 1936. . The General Theory of Employment, Interest and Money. London: Macmillan.

LAIDLER, D.; PARKIN, M. Inflation: a survey. Economic Journal, 85 (December), p. 741809, 1975.

MANKIW, N.G. The inexorable and mysterious tradeoff between inflation and unemployment. Economic Journal, 111 (May), p. C45-C61, 2001.

MCCALLUM, B.T. Monetary policy analysis in models without money. Federal Reserve Bank of St. Louis Review, v. 83, n. 4, p. 145-160, 2001.

MEYER, L.H. Does money matter? Federal Reserve Bank of St. Louis Review, v. 83, n. 5, p. 1-15, 2001.

ROWTHORN, R. E. Unemployment, age bargaining and capital-labour substitution. Cambridge Journal of Economics, v. 23, n. 4, p. 413-426, 1999.

SAWYER, M. Neither new nor Keynesian: A critique of the new Keynesian programme. METU Studies in Development, v. 35, n. 1, p. 61-80, june, 2008.

TAYLOR, J.B. Discretion Versus Policy Rules in Practice. Carnegie-Rochester Conference Series on Public Policy, p. 195-214, december, 1993.

Staggered wage and prices in macroeconomics. In: TAYLOR J. B.; WOODFORD, M. (eds.). Handbook of Macroeconomics, v. 1B, Amsterdam: North-Holland, 1998.

WICKSELL, K. Geldzins und Güterpreise, Verlag Gustav Fischer: Frankfurt. English translation. In: R.F. Kahn (1965), Interest and Prices, Kelley: New York. 1898.

WOODFORD, M. Interest and Prices: Foundations of a Theory of Monetary Policy, Princeton: Princeton University Press, 2003. 
Impressão e Editoração:

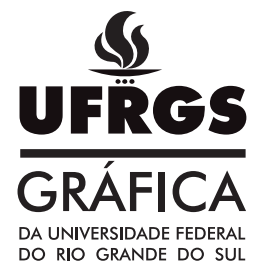

